\title{
Literacy Journeys Through Metaphor Projects with Preservice Teachers
}

\author{
Jan Buley \\ Memorial University of Newfoundland \\ jbuley@mun.ca
}

\begin{abstract}
This article examines the creation of literacy metaphor projects with teacher candidates. The article highlights the partnering of visual arts with storytelling in ways that illuminate how metaphors can clarify one's perceived roles in the classroom. With accompanied narratives, the metaphor projects paint a picture that reflects how the process can deepen and disrupt the practice and assumptions of educators.
\end{abstract}

\section{Introduction}

This article examines the creation of literacy metaphor projects with teacher candidates I taught, and their accompanying stories and reflective writing. It showcases the partnering of visual art with storytelling in ways that continue to surprise me - the author and teacher-learner. I believe that sharing the metaphor art creations can show teacher candidates the reality of the classroom environments they will meet. With accompanying narratives, the metaphor arts projects paint vivid pictures of the preservice teachers lived experiences and thinking. It also highlights the different types of learners in classroom settings. To paraphrase Lakoff and Johnson through metaphor, we meet ourselves and the lives of others (p. 82).

\section{The Orchestra Conductor}

In my first year of teaching, I was sure that I was the head conductor of the orchestra in the classroom. I alone decided what parts would be in my orchestra, and where various instruments and voices would enter the ensemble. I determined when I would weed out the weaker players and partner them with stronger musicians. I made choices about which curriculum documents were most pleasing to the classroom orchestra, and I assessed the growth of the performers based on my own findings, observations and rules. I decided where the players sat from week to week. I decided when they would have a break and when they could go to the bathroom. I evaluated the performances of each player with superficial judgment, and rarely stepped back to assess the quality of the conductor of the orchestra - me! I made the decisions about who needed more practice and who didn't. I was fully in charge from my desk. I shudder thinking about this metaphor now, but the construction of my orchestra metaphor at the time was clear: I was solely in charge of my learners, and the classroom progress was my responsibility. I viewed myself as an authoritative figure in the classroom, and rarely saw my students as being co-educators with each other and/or with myself.

Now, with over twenty-five years of reflecting about teaching and learning, metaphors have played a prominent role in my philosophy and practice. I now recognize my role as being a gentle guide on the side. My students are often my conductors; giving me helpful and

Cultural and Pedagogical Inquiry, Summer 2018, 10(1), pp. 22-31

ISSN 1916-3460 (C) 2018 University of Alberta

http://ejournals.library.ualberta.ca/index.php/cpi/index 
constructive guidance along our learning pathways together. Years ago, I remember being a student in a Master's course where I was invited to bring in something that made me squirm. We were asked to reflect on a powerful teachable moment and attempt to capture it with an object for sharing. With considerable trepidation, I brought in a spelling test I had designed. I also brought in a copy of the famous 'Friday Spelling Test' completed by an underachieving grade three student named Ethan. Ethan was often in tears at spelling time, dreading the outcome of the list I barked out week after week. He often had eighteen of the twenty words spelled incorrectly, and I can recall circling them and writing: "Come and see me right away" across the top of his test. He dutifully wrote each incorrect word five times. His mother joined me in this punishment. I saw little progress but continued flogging the dead horse, convinced that the correct spellings would somehow magically travel up Ethan's wrist and arm, eventually reaching his brain. He continued to fail spelling miserably and eventually moved away. Again, I shudder at this memory, but the experience of sharing these metaphors of teaching burns in my memory. The day I shared this story in my Master's class, there were also other artifacts shared by my peers: Red pens, a list of cruel report card comments, a strap, a bottle of pills, and a list of teacher-designed rules for the classroom at the beginning of the academic year.

This experience of sharing my attitudes and experiences in this way stayed with me as a powerful turning point in my own teaching career, so each year, I now include 'The Literacy Metaphor Project' with preservice education students. Beginning educators may not yet have authentic classroom teacher experiences, but they have rich experiences from their own lived lives as students in elementary and high schools. The directions in the course syllabus are intentionally broad, for example, 'Show some aspect of your literacy journey through sculpture, photography, performance, literary device, music or a surprise'. There is only one rule: A written essay is not permitted. I would argue that it's relatively easy to hide behind the mask of some written commentary about 'what matters most' in one's teaching journey. I can sit at a computer and go on for hours about what I believe is critical for developing reading comprehension, or how to teach a poetry unit effectively, or what kills a love of literacy. But to show an aspect of one's learning through poetry, sculpture, performance, or art is another task entirely. Graeme Sullivan (2010) speaks of 'visual knowing' when we are called upon to represent a story through creative ways. Not only is the creator challenged in 'showing' the story, but the viewer is invited and challenged to make very personal connections to what they are seeing or witnessing.

Initially, some students panic at the idea of creating something to show an aspect of their literacy journey. They're used to writing papers and handing them in to a professor for a mark. They are accustomed to being given a topic and submitting something that is a certain word count in length. But we spend a lot of time talking about possibilities, and I also share some past examples to get ideas flowing. I assure them that the sky is the limit for their creative sharing and urge them to trust themselves: "Start by thinking back to a powerful moment that stands out for you," I offer. "And then think about how you might show that incident through a sculpture, painting, collage, performance, etc. What might that look like?"

Trust is a crucial part of this process, as risk-taking will only happen if students truly believe in the process and in the sincerity of the learning invitations. When the student-teachers with their projects arrive in class, we transform the space into an art gallery, where we are invited to wander, snoop, examine and wonder about each other's projects. It is the sharing of

Cultural and Pedagogical Inquiry, Summer 2018, 10(1), pp. 22-31

ISSN 1916-3460 (C) 2018 University of Alberta http://ejournals.library.ualberta.ca/index.php/cpi/index 
these metaphor projects publicly - showing who we are, who we were and who we are becoming - that requires substantial vulnerability and courage. I see strong connections to the shedding of a snakeskin when these projects are shared. I, too, have shed many layers of my 'teaching skin'. For therein lies the metaphor for growth - the necessary 'outgrowing' of an old layer to a new layer of renewal and reflection about what we are becoming.

\section{The Art Projects, The Stories}

Metaphors help us clarify the relationships we have with others. They also illuminate the teacher we are, the teacher we were, and the teacher we hope to become (Gillis \& Johnson, 2002). When we share our metaphor projects in class, we discover incredible details about each other; things that might have been hidden. The stories that accompany these projects help to convey the meaning, emotion, and memories behind the selected metaphor ${ }^{1}$. Stories can connect the dots between the creation and the creator while pulling on the affective parts of the brain. Stories also offer further opportunities for audience members to empathize with the motivation behind the project (Carless \& Sparkes, 2008; Fivush, 2008). As explained by Gersie and King, stories are surely "...the gatekeepers between our inner and outer worlds and they exist at the very heart of who we are and what we might become" (1990, p. 35). In the following stories, student voices are recaptured from memory.

The Lampshade: Basketball-playing Jake lollops into class with his project on Monday morning. From his large backpack, he pulls out a table lamp. He removes the lampshade from a green garbage bag. The bulb is missing and he covers the ivory-coloured lampshade with a cone of heavy black paper. I watch him intently as he assembles things prior to sharing, curious about the connection to a student I barely know. What is the lamp signifying, I wonder? Only when he explains his story and reasoning for choosing the lamp, do we discover that Jake was Deaf until he had cochlear implants in grade one. As he is talking, Jake screws the lightbulb into the lamp and turns it on. The black cover on the lampshade continues to block out most of the light through the shade. "This is how I felt. Kind of in the complete dark until I got my implants. Sometimes my mom would read to me and point to the pictures, but I couldn't hear the story." Then Jake lifted the cone from the lampshade. Glued to the delicate ivory shade we read the following typed words: 'MUM, Dr. Seuss, laughing with my brothers, dinner table talk, hockey practice, piano lessons, story time, knock-knock jokes, success in school'. In Jake's personal experience, his metaphor represented his own early literacy learning challenges, and we all gained insight into Jake's early years in school. After learning about Jake's story, one student wrote in her journal that she will now "be watching and listening for the stories students and parents share with me. Realizing what Jake went through has awakened me to the possibility that I might have a student just like him in my class some day."

I know I am richer having heard Jake's story too, and have often reflected on what I discover through the sharing of the metaphor projects. Like Karen Gallas (1994), I believe that we must come to know the learners in our midst before we attempt to 'teach' anything. This means going beyond the 'surface stuff' of knowing names, asking for book club money or inquiring about homework. We need to know more about families and support networks for the students we are teaching and learning with. Providing opportunities for learners to share who they are is key to creating a supportive classroom climate where everyone feels that they matter.

\footnotetext{
${ }^{1}$ In this article, the author remembers the students' words, as fully as possible.

Cultural and Pedagogical Inquiry, Summer 2018, 10(1), pp. 22-31

ISSN 1916-3460 (C) 2018 University of Alberta

http://ejournals.library.ualberta.ca/index.php/cpi/index
} 
Gallas (1994) says that "if the learner is to participate fully in the community of the classroom, with its diversity of language and culture, then all members of the community, children and teachers alike, must participate and join in the community of each child" (p. 18).

The Maze: Matthew has created a maze as his metaphor for his literacy learning journey. He has constructed the maze inside a large box on the floor, using folded newspaper for the walls and various pages from essays he's written at university over the years. At first glance, his project is a chaotic one with wild pathways crisscrossing the boxed boundaries. When followed, the maze leads to a dizzying array of dead-ends: his metaphor for how he felt about reading through most of his elementary and high school years. "I would pick a book that I thought was just right and then find out that I was lost. Repeatedly lost. I was just turning the pages and not understanding anything. Other times, a novel was assigned and I wasn't interested in reading it at all. I'm a history major now, so the reading in university was intense and I often resorted to faking my way through class discussions. I'm okay with maps and visuals, but the sheer amount of reading in my undergrad nearly killed me. I didn't really know where to turn for help in high school so I sometimes just gave up. This project really got me thinking about kids who I'll be teaching who are just like me."

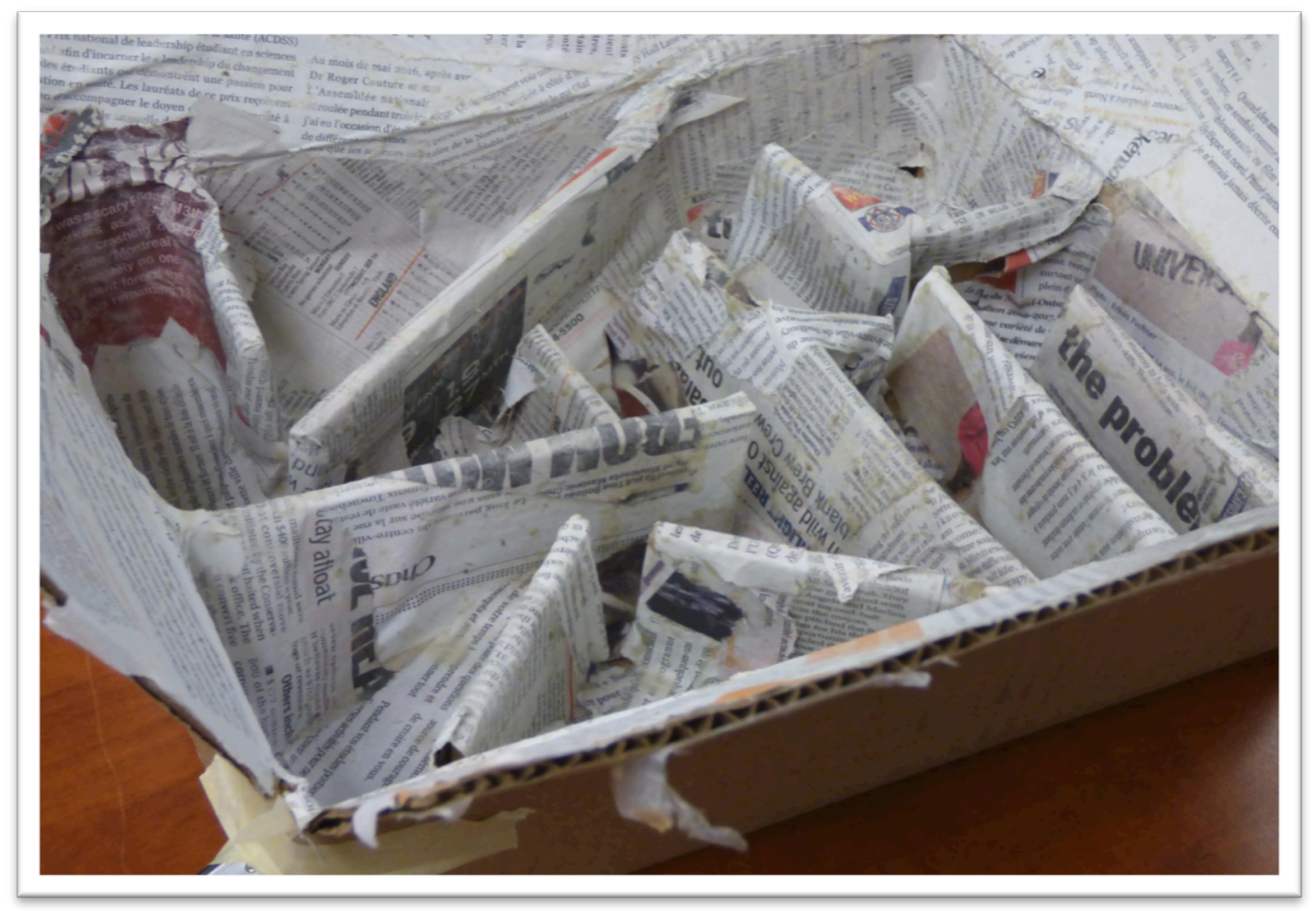

Cultural and Pedagogical Inquiry, Summer 2018, 10(1), pp. 22-31

ISSN 1916-3460 (C) 2018 University of Alberta

http://ejournals.library.ualberta.ca/index.php/cpi/index 
The Treehouse: Katrina's metaphor captures a much more positive experience with literacy. She literally bubbles with enthusiasm as she walks us through her project. It's a painstakingly constructed treehouse, transported on the city bus to the university! "I got lost in the books I read as a kid, too. But not lost in the way you got lost, Matthew. I got lost in a good way. It was like I was in some magical treehouse, reading book after book after book. My mother would call me to come for dinner or something and sometimes I wouldn't even hear her, because I'd be so absorbed in a book. Funny thing, but I never had a treehouse. I always really wanted one though. My bedroom window looked out over our backyard and there was this enormous tree growing there and it shaded almost the entire lawn. It was huge. For my tenth birthday, my Mom made me a set of big puffy floor cushions that I could sit on by the window and it was like my own private little library space. Almost like being in a treehouse, because the branches of that big tree would touch my windowpane. It was pretty magical, really. I used to adore sitting in that window on my pillows reading and gazing out at the big maple tree in our backyard. And it's weird, now, to think about two of my favourite novels growing up: A Tree Grows in Brooklyn and Diary of Ann Frank - both with trees highlighted in them. Both are stories about powerful girls who grew up in a time and place that I loved reading about."

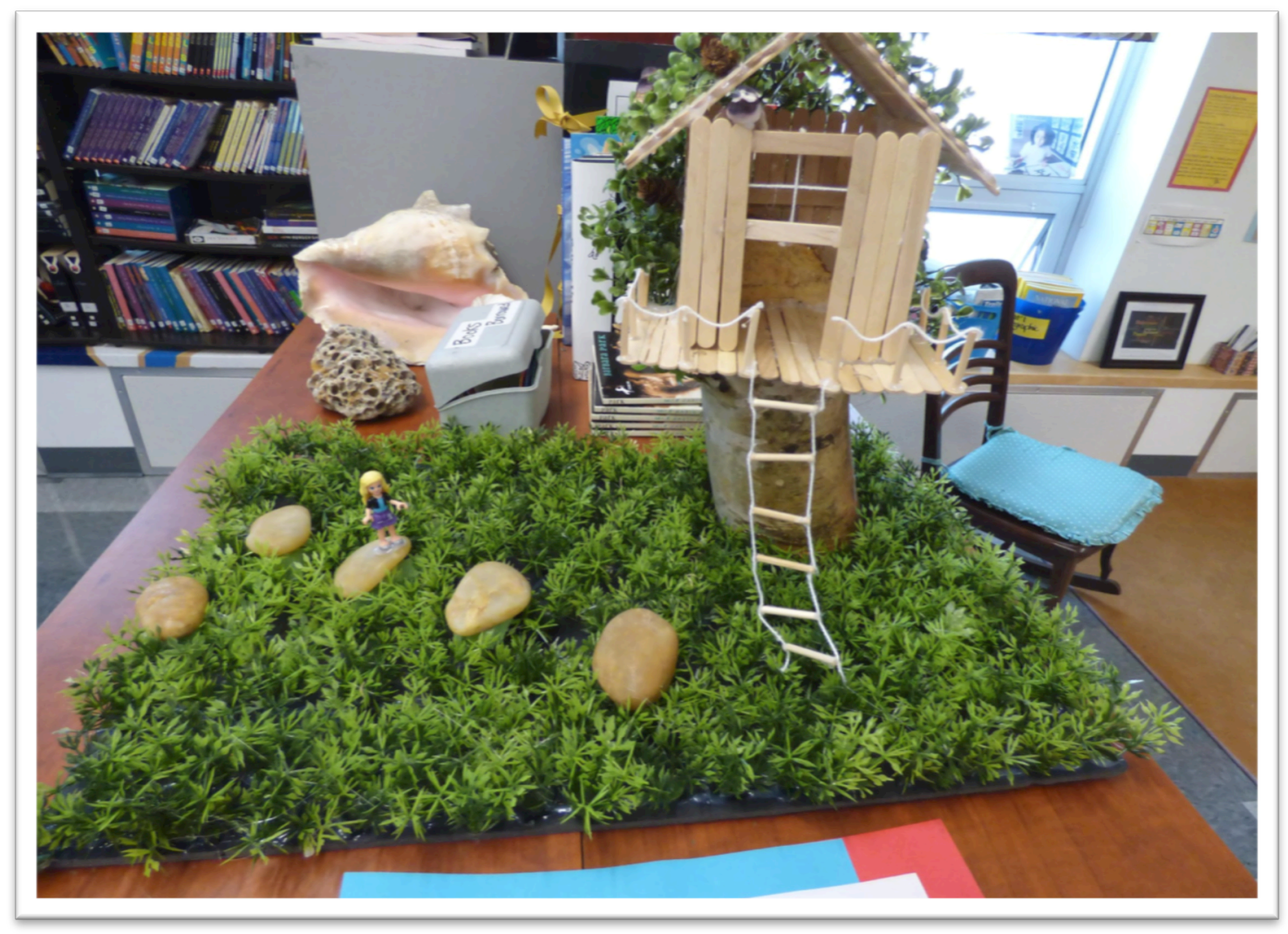

The Cardboard Shield: Then it's Amy's turn to share. She holds up a large cardboard shield with favourite book titles glued onto it in big colourful letters. Clearly visible are Charlotte's Web, Harry Potter and A Wrinkle in Time. Around the edge of the shield are the titles of picture books Amy loved as a kid: The Cat in the Hat, The Very Hungry Caterpillar, Harry the Dirty Dog. She reads them aloud as we listen to the list unfolding. Heads nod. Clearly, these are favourite books for others in the room. Then without saying anything, Amy turns the

Cultural and Pedagogical Inquiry, Summer 2018, 10(1), pp. 22-31

ISSN 1916-3460 (C) 2018 University of Alberta

http://ejournals.library.ualberta.ca/index.php/cpi/index 
shield over to reveal the other side of the cardboard. She doesn't say anything, but in large black and white type are other words: suicide, depressed, fat, silent, hated, hidden. Amy's bottom lip trembles and she peers straight ahead into the eyes of her classmates. Tears begin falling down her cheeks, and then I realize that I am crying too. We learn that books were Amy's shield from a world of verbal abuse and low self-esteem about her body size. We discover that for Amy, books were her refuge. Books allowed her to retreat into a world where she was accepted for who she was and is. We learn that she is courageous, passionate and resilient. The entire class rises and we applaud Amy's sharing and vulnerability. Because of her project and story, we are all driven to discover more about the learners in our midst, for their stories can shape our practice in powerful ways.

The Bird: Darren created a beautiful box with a perfectly poised bird hovering over the lid of the box. "I have always been fascinated by reading books both presently and in my past. As a young boy, the escape to fantasy and science fiction offered me a sort of freedom from the day to day events in a busy life. I had a tough time in high school after my Mom died of cancer. Books carried me through. The bird on top of the box represents the freedom I felt. He's actually hovering just a little bit above the globe, signifying the escape from the world. Books gave me that freedom. I enjoyed reading science fiction and fantasy the most because they fueled my extremely vivid imagination. Like Carl Sagan's quotation says inside the lid of my box, books are like time machines connecting people from different cultures and ages of the past. That's why I included the picture of the clock. It's a reminder of the time machine and the importance of time with books in my life. For me, this truly makes books a sort of real life magic, and that's what I've tried to show with this box when you lift up the lid and peer inside."
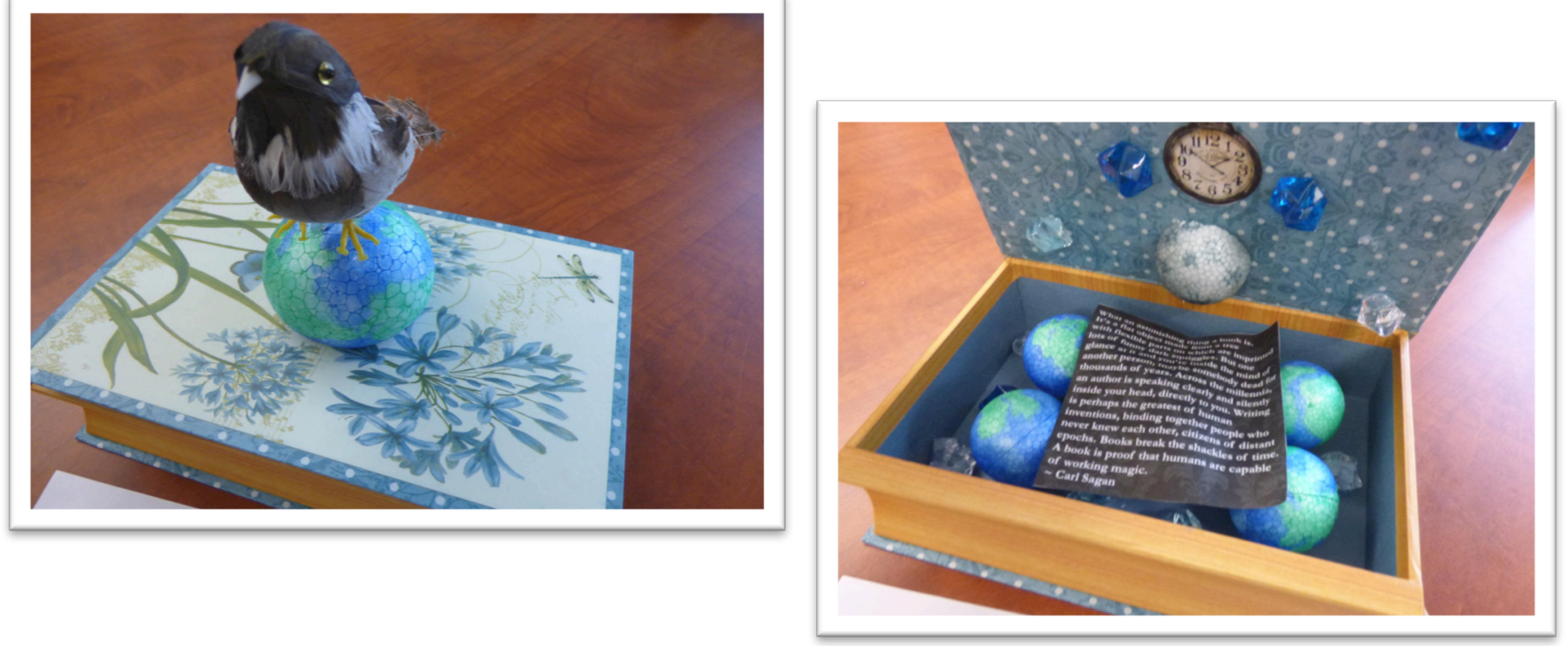

Cultural and Pedagogical Inquiry, Summer 2018, 10(1), pp. 22-31

ISSN 1916-3460 (C) 2018 University of Alberta

http://ejournals.library.ualberta.ca/index.php/cpi/index 
The use of metaphor with teacher candidates can clarify for others and for ourselves, how we perceive our roles in the classroom. The sharing of metaphor creations can also show teacher candidates the reality of the classroom fabric they may be encountering. The metaphor projects and stories create a clearer picture of the kinds of learners that exist in the world of the classroom. The sharing we do helps to illuminate the lives of the learners who may be met in schools. As Lakoff and Johnson (1980) point out, through metaphor, we meet ourselves and others. I will argue that because of the metaphor project sharings, we are better able to deepen our understandings of the classroom community.

"Words create worlds" (Whitney \& Trosten-Bloom, 2003, p. 53). The sharing of stories and personal experiences, our previous schooling and our early formative interactions with others can shape our thinking later in life. Jennifer's metaphor for her literacy journey is a doorknob. She tells everyone that she found it in a second-hand store, and she chose it specifically because it appears as if someone has forced a sharp object into the keyhole unsuccessfully. Perhaps the person was locked out, I mumble aloud, as I wander around the classroom examining the other metaphor projects. Or maybe books provided a secret doorway into a more positive school experience.

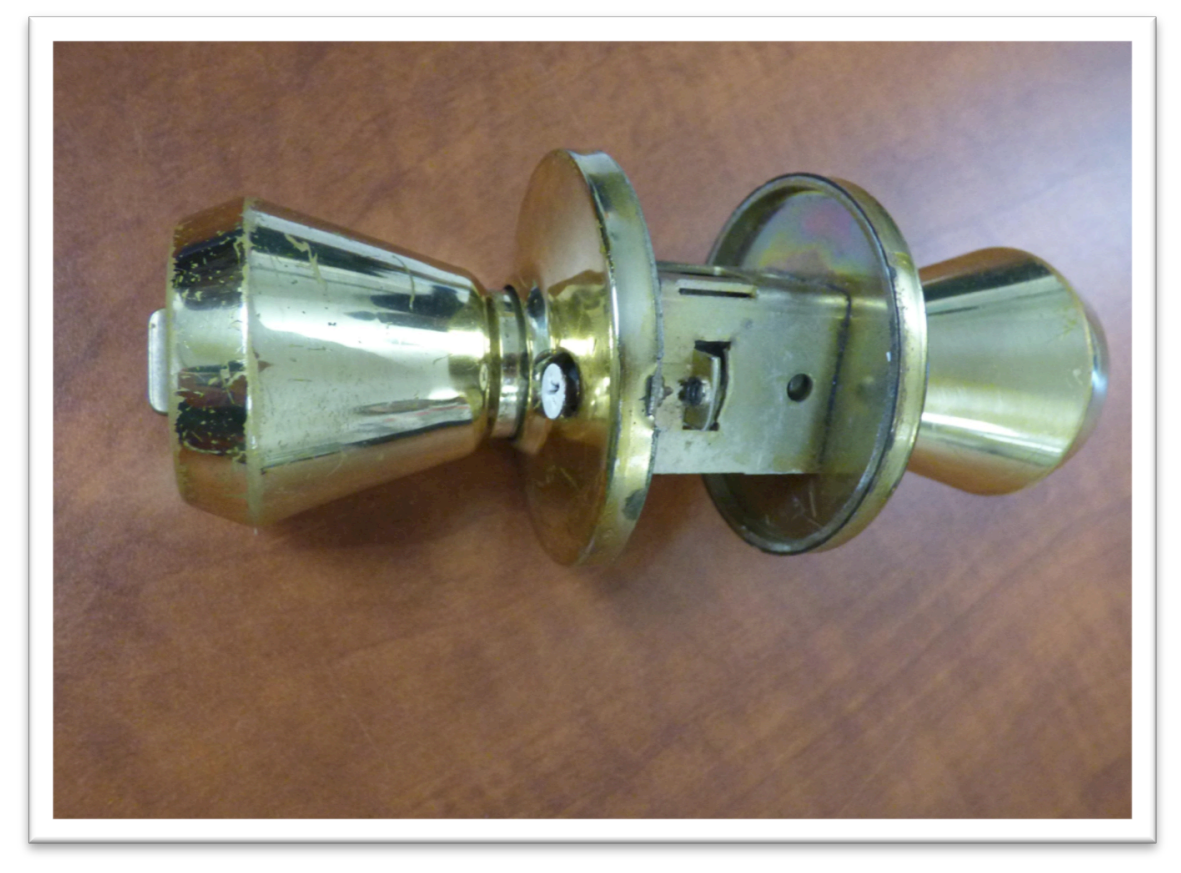

In her reflective piece accompanying her project, Jennifer further clarifies her connection to the doorknob metaphor for her literacy journey. She explains that when she was in grade six, she was bullied by a group of girls in her class. She dreaded going to school. She would try to lie to her mother about migraines and homework. And she often recalled the fear with which she closed the door to her house behind her as she left for school. "Slowly, I turned the doorknob of my house to leave for school. It would click shut, and I can remember thinking that this was the one place where I felt safe. Once outside the door of my house, however, I dreaded what I would face." At recess, Jennifer had no-one to hang out with, so she would often take a book outside and pretend to read it. Jennifer was not a strong reader by any means, but the books became the wall between her and the bullies. And little by little, she became a more competent reader:

Cultural and Pedagogical Inquiry, Summer 2018, 10(1), pp. 22-31

ISSN 1916-3460 (C) 2018 University of Alberta

http://ejournals.library.ualberta.ca/index.php/cpi/index 
On the outside, it looked like I was doing just fine. I hid my emotions quite well but I continued to feel like an outsider. I walled myself into my own insecurities until finally, I closed the door shut. Permanently. I had a door at school that was like a reinforced door to a fortress. Nobody could get in. I was constantly on the outside of the cliques, the teams, the parties, the class activities. But bit by bit, I started to open up the door a crack to a friend or two I could trust. Books and reading and escaping into other worlds were always places I could turn to. Books allowed me to escape into other worlds where I could be anyone I wanted to be. Where I was in charge. I was never bullied. I was a World War II pilot. I was a fantasy character helping others to be strong. I was living on the beach waiting to catch the perfect wave. I was a caribou crossing the Arctic with the herd. Reading was my escape. It gave me comfort. I could forget the rest of the bullying world around me, reach for the key to unlock the door and turn off the world around me. Books meant that I could push the reset button every night and wake up the next morning better prepared to tackle my social challenges. Slowly I became accepted for who I was. I found friends in books and with a few others who also loved books. The door opened.

The way we encounter a situation or experience affects the way we describe it. The way we talk (or write) about something affects the way we create our personal beliefs and viewpoints in life. The reaction we have to someone or something affects the way we experience it, and the way we experience something affects the way we later think about the encounter with someone or something. If you think about the first time you went walking through a forest, you may recall a sunny day with friends on a pleasant hike. Maybe you found a nest, and someone pointed out the way it was constructed. You might have encountered deer hoof footprints in the mud beside a stream. When you stand perfectly still and listen, perhaps there is evidence of a squirrel chattering noisily from a pine branch overhead. If, however, your first trip to a forest involves getting caught in a thunderstorm and then becoming lost, it's quite likely that your next opportunity to visit a forest will be influenced by your first encounter there. Perhaps you will equate a forest with fear, until something new happens that turns this experience around. For some students, book encounters are like getting lost in a forest with no clear pathway to follow. For others, the sun shines brightly and there are invigorating surprises at every turn. When we signify things through one metaphor rather than another, we are constructing our reality one way rather than another. Metaphors structure the way we think and the way we act, and our systems of knowledge and belief, in a pervasive and fundamental way (Fairclough, 1992).

\section{Final Thoughts}

Louise Rosenblatt (1938) argues that "literature makes comprehensible the myriad ways in which human beings meet the infinite possibilities that life offers" (p. 6). Through transactional reading, we are able to walk in the shoes of a character or live through the life of the creatures in the story. One's understanding of a novel or picture book is enhanced when a personal connection is made to the challenges the character is facing, where the story takes place or how various problems are solved. Sometimes we begin to understand more about our own philosophies and assumptions through the decision-making of a character in a book we are reading. Sometimes through these interactions, we discover who we are and who we are not. Indeed, Pajak (1986) and Clandinin (1986) believe that exploring metaphors can be a means for teachers to verbalize and show their "professional identity". Many preservice teachers have clear

Cultural and Pedagogical Inquiry, Summer 2018, 10(1), pp. 22-31

ISSN 1916-3460 (C) 2018 University of Alberta

http://ejournals.library.ualberta.ca/index.php/cpi/index 
beliefs about their role in the classroom and it is these beliefs that shape their behaviours and interactions in their teaching and learning. In a casual discussion with preservice teachers, I overheard one of them say that she felt like she was the 'head gardener' in the classroom. 'I' $m$ in charge of watering, weeding and making sure that the seedlings are growing each day", Emily said emphatically. Her metaphor project involved a vase of artificial flowers, but in her accompanying story, she added that "sometimes the kids are in charge of the garden. I become transplanted. They cause me to bloom in ways that surprise me when I let them take control of where things go and grow. Like sometimes the kids in my class need to water me and help me grow where I am." Through her narrative, Emily found new and deeper connections to her garden literacy metaphor.

The metaphor projects can transform and change our thinking. The metaphor projects can be wonderful ways for peers to see common themes within literacy learning experiences. They have provided - and continue to provide — conduits for conversation and rich exchange, forcing us to face our assumptions about teaching and learning, and nudging us to clarify our attitudes and beliefs. Last month, I received an email from Emily, an education student I taught five years ago. In her message, she told me that she had asked her grade eight students to create a 'literacy memory' of some part of their journey as readers and writers. "I learned something new about every single student in my class, Jan. It's funny, but I still remember the fish in the fishbowlhow that guy always felt like he was being observed by the teacher and couldn't escape." I was delighted to know that Emily's experience with me had prompted her to include a similar project with her own students. I told her that I often think about the fish in the fishbowl metaphor too. We both recognize the value in getting to know the students in our classrooms more fully. Clearly, the metaphor projects have the potential to elicit much personal reflection about language teaching and learning for preservice and practicing teachers alike.

So I return to the questions at the opening of this paper: How might the literacy metaphor creations and accompanying stories help us to discover who we are as teachers and learners? How might they deepen and disrupt the practice and assumptions of educators? Often, the projects invite all of us to step back and re-examine our own literacy learning experiences and assumptions - the good, the bad and the ugly. We discover that, like someone else, we have also been humiliated because of a teacher's response to a writing exercise. We find common ground with someone who shares how they vicariously lived through the strongest character in a novel. We can relate to a peer's story of fearing public speaking contests. And we are invited to reflect upon the cruelty of 'one size fits all' testing for reading competencies. Ultimately, these projects invite connections. They often cause some internal squirming for the viewer and for the creator, long after the projects have physically disappeared from the classroom. I continue to revisit the projects I've seen and experienced over the years, and they have impacted my thinking. Certain puncture points or painful teachable moments come alive for the creator of the projects when they unpack their connections through sculpture and story. We are able to see ourselves in the works of others. And if we are willing, the projects have the potential to poke us awake in unpredictable ways, shake up our assumptions about what matters most in literacy learning, and prod us to reflect on ways we might improve our own practice bit by bit. 


\section{References}

Carless, D. \& Sparkes, A. C. (2008). The physical activity experiences of men with serious mental illness: Three short stories. Psychology of Sport and Exercise, 9(2), 191-210. doi:10.1016/j.psychsport.2007.03.008

Carle, E. (1987). The very hungry caterpillar. New York, NY: Penguin Young Readers Publishing.

Clandinin, D. J. (1986). Classroom practice: Teacher images in action. London, Falmer Press.

Fairclough, N. (1992). Discourse and social change. Cambridge, Massachusetts: Polity.

Gallas, K. (1994). Gallas, K. (1994). The languages of learning: How children talk, write, dance, draw, and sing their understanding of the world. New York: Teachers College Press.

Fivush, R. (2008). Remembering and reminiscing: How individual lives are constructed in family narratives. Memory Studies, 1(1), 49-58. doi:10.1177/1750698007083888

Frank, A. (1996). The diary of Anne Frank. Chicago, IL: Knopf Doubleday Publishing Group.

Gersie, A. \& King, N. (1990). Storymaking in education and therapy. London: Jessica Kingsley Publishers.

Gillis, C., \& Johnson, C. L. (2002). Metaphor as renewal: Re-imagining our professional selves. The English Journal, 91(6), 37-43. doi:10.2307/821814

Lakoff, G. \& Johnson, M. (1980). Metaphors we live by. Chicago: University of Chicago Press.

L'Engle, M. (2018). A wrinkle in time. New York: Faber and Faber Publishers.

Pajak, E. F. (1986). Psychoanalysis, teaching and supervision. Journal of Curriculum and Supervision, 1, 122-131. Retrieved from: http://www.ascd.org/publications/jcs/summer2005/toc.aspx

Rosenblatt, L. (1938). Literature as exploration. Chicago: Modern Language Association.

Rowling, J. K. (2014). Harry Potter and the goblet of fire. London: Bloomsbury Press.

Seuss. (1995). The cat in the hat. London: HarperCollins Children's Book Publishers.

Smith, B. (1943). A tree grows in Brooklyn. New York: Harper Collins Publishers.

Sullivan, G. (2010). Art practice as research: Inquiry in visual arts. Thousand Oaks, CA: Sage.

White, E. B. (1952). Charlotte's web. New York: Harper Collins Publishers.

Whitney, D. \& Trosten-Bloom, A. (2003). The power of appreciative inquiry: A practical guide to positive change. San Francisco, CA: Berrett-Koehler Publishers, Inc.

Zion, G. (1956). Harry the dirty dog. New York: Harper Collins Publishers.

Cultural and Pedagogical Inquiry, Summer 2018, 10(1), pp. 22-31

ISSN 1916-3460 C 2018 University of Alberta

http://ejournals.library.ualberta.ca/index.php/cpi/index 